\title{
ANTIBACTERIAL AND ANTIOXIDANT ACTIVITY OF LICHENS Usnea rubrotincta, Ramalina dumeticola, Cladonia verticillata AND THEIR CHEMICAL CONSTITUENTS
}

\section{(Kajian Aktiviti Antibakteria dan Antioksidan Liken Usnea rubrotincta, Ramalina dumeticola, Cladonia verticillata dan Sebatian Kimianya)}

\author{
Saranyapiriya Gunasekaran ${ }^{1}$, Vinoshene Pillai Rajan ${ }^{1}$, Surash Ramanathan ${ }^{2}$, Vikneswaran Murugaiyah $^{3}$, \\ Mohd. Wahid Samsudin ${ }^{1}$, Laily B Din ${ }^{1}$ \\ ${ }^{1}$ School of Chemical Science and Food Technology, Faculty of Science and Technology \\ Universiti Kebangsaan Malaysia, 43600 UKM Bangi, Selangor, Malaysia \\ ${ }^{2}$ Centre for Drug Research \\ ${ }^{3}$ School of Pharmaceutical Sciences \\ Universiti Sains Malaysia, 11800 Gelugur, Penang, Malaysia \\ *Corresponding author: saranyapiriya89@gmail.com
}

Received: 24 August 2015; Accepted: 4 November 2015

\begin{abstract}
The present study was carried out to evaluate the antibacterial and antioxidant activity of extract and chemical constituents of Usnea rubrotincta, Ramalina dumeticola and Cladonia verticillata. Acetone extract of $U$. rubrotincta showed promising antibacterial activity against Gram positive bacteria Bacillus subtilis with the lowest Minimal Inhibitory Concentration (MIC) value of $(15.63 \mu \mathrm{g} / \mathrm{mL})$. Six secondary metabolites were isolated using Preparative High Performance Liquid Chromatography (PHPLC) method from the two bioactive lichens $U$. rubrotincta and $R$. dumeticola (compound $1-6$ ). Among all six compounds, compound (1) exhibited strongest activity against both the tested Gram positive bacteria at $7.81 \mu \mathrm{g} / \mathrm{mL}$. Compound (6) had $69.57 \%$ scavenging activity against DPPH free radical while the rest only showed below 50\% scavenging activity. This is the first evaluation of antibacterial activity of lichens found in Malaysia and to our knowledge, this is the first report of antibacterial and antioxidant activity of compound (3) and (5).
\end{abstract}

Keywords: antibacterial, antioxidant, Usnea rubrotincta, Ramalina dumeticola, Cladonia verticillata, usnic acid

\section{Abstrak}

Kajian ini dijalankan bagi menilai aktiviti antibakteria dan antioksidan sebatian kimia liken yang diekstrak iaitu Usnea rubrotincta, Ramalina dumeticola dan Cladonia verticillata. Ekstrak aseton terhadap U. rubrotincta telah menunjukkan aktiviti antibakteria yang memberangsangkan terhadap bakteria Gram positif Bacillus subtilis dengan nilai Kepekatan Perencatan Minimum (KPM) sebanyak $(15.63 \mu \mathrm{g} / \mathrm{mL})$. Enam metabolit sekunder telah dipencilkan daripada 2 liken bioaktif iaitu $U$. rubrotincta dan $R$. dumeticola menggunakan kaedah Kromatografi Cecair Prestasi Tinggi Preparatif (KCPTP) (sebatian 1 - 6). Daripada 6 sebatian, sebatian (1) telah memaparkan aktiviti yang paling kuat terhadap kedua-dua bakteria Gram positif yang dikaji pada kepekatan $7.81 \mu \mathrm{g} / \mathrm{mL}$. Sebatian (6) mempunyai peratus pemerangkapan radikal bebas DPPH pada $69.57 \%$ manakala sebatian lain hanya menunjukkan aktiviti pemerangkapan kurang daripada 50\%. Ini adalah penilaian pertama terhadap aktiviti antibakteria bagi liken yang dijumpai di Malaysia dan kepada pengetahuan kita, ini adalah laporan pertama bagi aktiviti antibakteria dan antioksidan sebatian (3) dan (5).

Kata kunci: antibakteria, antioksidan, Usnea rubrotincta, Ramalina dumeticola, Cladonia verticillata, asid usnik 


\section{Introduction}

Lichens are self-supporting symbiotic association between a mycobiont and a photobiont. The mycobiont which is the fungus is unique and dominates the association while the photobiont is the algae or cyanobacteria. Many lichens are able to endure extreme environmental conditions hostile to the survival of the individual partners [1]. They are able to grow as scattered patches on stones, outcrops, on tree trunks or shrubs. Lichens mostly expose their vegetative parts to sunlight to enable the photobiont which harvest energy from solar radiation. These vegetative bodies are called thalli or lichenized stroma which contains characteristic secondary compounds [2].

To date approximately 1050 secondary metabolites have been identified [3] and most of them are considered to be very unique. The secondary metabolites found in lichens were reported to have multiple functions. They are light filters that protect the photobionts from excessive radiation [4], prevent damage from grazing by herbivores and have antibiotic properties to protect against microbial degradation [5]. Compounds like atranorin, fumarprotocetraric acid, gyrophoric acid, lecanoric acid, physodic acid, protocetraric acid, stictic acid and usnic acid have showed comparatively strong antimicrobial properties against bacteria and fungi, amongst which were human, animal and plant pathogens, mycotoxin-producers and food-spoilage organisms [6]. Several depsides (sekikaic acid, lecanoric acid and lobaric acid) are known exhibited radical scavenging activity comparable to rutin [7].

There are compelling reasons for the search of new antimicrobial agents, including from natural product drugs mainly because of the emergence of multi drug-resistant pathogens and the reduced effectiveness of currently used drugs. Besides, the rise of various diseases related to oxidative stress implicates the dire need of discovery of new antioxidant agents. Lichens can be a good source for the search due to the ability to survive in extreme conditions. Malaysia is abundant of highland and lowland lichens. Din et al. [8] profiled several types of chemical compounds derived from lichens collected from Bukit Larut, Peninsular Malaysia some of which have been reported previously to possess strong antibacterial and antioxidant activity. Four lichen species namely Ramalina peruviana, Parmotrema tinctorum, Bulbothrix isidiza and Cladia aggregata from Penang Hill, Malaysia were found to have significant antioxidant activity [9]. Hitherto there is no report on the antimicrobial activity of the lichens found in Malaysia. This study investigated antibacterial and antioxidant potential of various extracts of three different lichens from the species, Usnea rubrotincta, Ramalina dumeticola and Cladonia vercillata collected from the Malaysian highland area. Further to this, work was undertaken to isolate the chemical constituents from the active lichen extracts.

\section{Lichen samples}

\section{Materials and Methods}

Lichen Ramalina dumeticola was collected from Fraser Hill, Pahang, $3^{\circ} 46$ N' $111^{\circ} 43$ E', 1300m above sea level, voucher specimen number (F.H 1). Lichen Usnea rubrotincta and Cladonia vercilata were collected from Bukit Larut, Perak, $4^{\circ} 50 \mathrm{~N}^{\prime}, 100^{\circ} 48$ E', 1035m above sea level, voucher specimen number (B.L 1, B.L 2). Voucher specimens of these lichens have been deposited at the School of Chemical Sciences and Food Technology, Universiti Kebangsaan Malaysia.

\section{Microorganisms and media}

The bacteria used as test organisms are as follows: Staphylococcus aureus (ATCC 29213), Bacillus subtilis (ATCC 19659) and Escherichia coli (ATCC 25922) obtained from American Type Culture Collection/USA). Bacterial cultures were maintained on Muller Hinton agar substrates (Oxoid Ltd., Hampshire, England) and were stored at 4 ${ }^{\circ} \mathrm{C}$.

\section{Preparation of lichen extracts}

The lichen samples were air dried at room temperature. Powdered lichen samples of $250 \mathrm{~g}$ were subjected to sequential soxhlet extraction with two types of solvent, acetone and methanol. All the extractions were repeated twice. The extracts were then filtered, concentrated in vacuo and air-dried under fume hood to obtain dry powdered extracts which were stored at $4^{\circ} \mathrm{C}$. 


\section{Antibacterial studies}

The minimal inhibitory concentrations (MIC) of methanol and acetone extract of the lichens were determined using the 96 well plate methods as described by Eloff [10] with some modification. Bacterial inoculums were obtained from bacterial cultures incubated for 24 hours at $37{ }^{\circ} \mathrm{C}$ on Müller-Hinton agar and diluted to $0.5 \mathrm{McFarland}$ standard of approximately $10^{8} \mathrm{CFU} / \mathrm{mL}$. The extracts were screened for antibacterial potentials at $500 \mu \mathrm{g} / \mathrm{mL}$. Extracts showing bacterial growth inhibition were further tested to evaluate its MIC. A two fold serial dilution of acetone extracts $(500-7.81 \mu \mathrm{g} / \mathrm{mL})$ in DMSO and methanol extracts in methanol were prepared in a sterile 96-well plate respectively. The percentage of solvent was kept below $1 \%$ throughout the experiment.

Bacterial suspensions $(100 \mathrm{~mL})$ were added to each well and the plates were incubated for 24 hours at $37^{\circ} \mathrm{C}$. After the incubation time, $50 \mathrm{~mL}$ of $p$-iodonitrotetrazolium $(p$-INT) $(0.2 \mathrm{mg} / \mathrm{mL})$ was added into all the wells, including the blank wells (containing methanol or DMSO), and further incubated for 1 hour. These plates were then observed for color changes. Wells with yellow color were interpreted as no growth, whilst purple color was interpreted as presence growth. The minimum inhibitory concentration (MIC) was determined as the lowest concentration of samples which inhibit any visible growth of bacteria. Chloramphenicol and vancomycin were used as positive controls $(500-7.81 \mu \mathrm{g} / \mathrm{mL})$. All experiments were performed in triplicate.

\section{Antioxidant assay: Total phenolic content}

Total phenolic content (TPC) were estimated by using the Folin - Ciocalteu method [11] with some modification. Stock solutions of $1 \mathrm{mg} / \mathrm{mL}$ extracts and gallic acid were prepared in DMSO and distilled water respectively. A series of gallic acid concentrations were prepared by diluting the stock solution with distilled water. Gallic acid of $250 \mu \mathrm{L}$ was added into individual test tubes followed by addition of $1 \mathrm{~mL}$ of distilled water and $250 \mu \mathrm{L}$ of Folin Ciocalteu reagent. After thoroughly shaken, the test tubes are allowed to sit in room temperature for 6 minutes. Later, an amount of $2.5 \mathrm{~mL}$ of $\mathrm{Na}_{2} \mathrm{CO}_{3}$ was added and allowed to sit for another 2 hours in a dark room at room temperature. A $200 \mu \mathrm{L}$ of solution from each test tube is transferred into 96-well plate and the absorbance were measured at $760 \mathrm{~nm}$ using a microplate reader. The experiments were performed in triplicates. Gallic acid $(0-$ $500 \mu \mathrm{g} / \mathrm{mL}$ ) was used for calibration of a standard curve. The result was expressed as gallic acid equivalents (GAE)/g dry weight of lichen material.

\section{Total flavonoids}

The total flavonoid content (TFC) was determined using colorimetric method as described by Sakanaka et al. [12]. An amount $125 \mu \mathrm{L}$ of $1 \mathrm{mg} / \mathrm{mL}$ extract or standard solution (quercetin) were mixed with $625 \mu \mathrm{L}$ of distilled water in a test tube. Sodium nitrite (5\%) solution of $37.5 \mu \mathrm{L}$ is then added and incubated for 6 minutes. Aluminium chloride (10\%) solution of $75 \mu \mathrm{L}$ was later added and the mixture was allowed to stand for another 5 minutes. Thereafter, $250 \mu \mathrm{L}$ of $1 \mathrm{M}$ sodium hydroxide was added. The mixture was brought up to $1.25 \mathrm{~mL}$ with distilled water and mixed well. The absorbance at $510 \mathrm{~nm}$ was measured immediately. Quercetin $(0.5-0.02 \mathrm{mg} / \mathrm{mL})$ was used to construct a standard curve. The results were expressed as quercetin equivalent (QE) per gram dry weight of lichen extract. The experiments were performed in triplicates.

\section{1, 1-diphenyl-2-picryl-hydrazyl (DPPH) free radical analysis}

A quantitative determination of free radical scavenging activity was measured by using DPPH assay as described by Shimada et al. [13]. The antioxidant activity was expressed as percentage scavenging of DPPH by extract compared to standard, Trolox. An amount of $20 \mu \mathrm{L}$ extract $(1 \mathrm{mg} / \mathrm{mL})$ was added into $180 \mu \mathrm{L}$ of $0.2 \mathrm{mM}$ of DPPH solution in 96-well plate. The plate was incubated for 20 minutes and kept in the dark. The same steps were repeated for standard Trolox. The percentage of scavenging was calculated from the absorbance of decolorization which obtained spectrophotometrically at $550 \mathrm{~nm}$. Scavenging of the DPPH radical by the sample was calculated according to the following Equation (1).

$$
\text { DPPH scavenging activity }(\%)=[A 0-A 1 / A 1] \times 100
$$

where $A 0$ is the absorbance of the control and $A 1$ is the absorbance of the sample. Free radical scavenging activity is expressed as the percentage of DPPH scavenging activity. The experiments were performed in triplicates. 
Isolation of chemical constituents from the bioactive extracts: Liquid-liquid extraction

$2 \mathrm{~g}$ of bioactive extracts were subjected to liquid-liquid extraction using hexane and methanol at 1:1 ratio. The process was performed in a triplicate. The resulting fractions were pooled and dried. It was noticed that there were crystals formed, which was filtered and purified further by recrystallization.

\section{Thin layer chromatography (TLC)}

The fractions were dissolved in appropriate solvent before being spotted onto the TLC plate. Solvent systems used in this thin-layer chromatography were according to Culberson [14] and Culberson et al. [15] namely (a) benzenedioxane-acetic acid (180:45:5, $230 \mathrm{~mL}$ ), (b) hexane-diethyl ether-formic acid (130:80:20, $230 \mathrm{~mL}$ ), (c) tolueneacetic acid (200:30, $230 \mathrm{~mL})$ and (d) toluene-ethyl acetate-formic acid (139:83:8, $230 \mathrm{~mL})$. The spots were viewed under long and short ultraviolet light before sprayed with $10 \%$ sulphuric acid and heated at $110{ }^{\circ} \mathrm{C}$.

\section{Column chromatography}

Fractions that showed good separation on the TLC plate was subjected to column chromatography. The solvent system used was similar to the one used for TLC. An approximately $0.5 \mathrm{~g}$ of the fraction was dissolved in a small amount of solvent system to avoid solubility problems inside the column. Small amounts of solvent were filled into the column every 15 minutes. The sub-fractions were collected according to the bands formed in the column and airdried before subjected to TLC.

\section{Preparative high performance liquid chromatography}

The column used for separation was a Phenomenex Hypersil $5 \mu \mathrm{C} 18$ column $(150 \times 21.2 \mathrm{~mm})$ with the gradient mobile phases of methanol (A) and $1 \%$ orthophosphoric acid (B) with a flow rate of $4 \mathrm{~mL} / \mathrm{min}$. The run started with $100 \% \mathrm{~B}$ and was lowered to $50 \% \mathrm{~B}$ within 5 minutes then to $40 \% \mathrm{~B}$ within a further 10 minutes, followed by $20 \% \mathrm{~B}$ within the next 30 minutes. Then $500 \mu \mathrm{g} / \mathrm{ml}$ of sample with the injection volume of $100 \mu 1$ was injected. A photodiode array detector was used to detect the compound peaks and recorded at three different wavelengths of $222 \mathrm{~nm}, 230 \mathrm{~nm}$ and $280 \mathrm{~nm}$. The fractions were collected according to the retention time.

\section{Identification of chemical constituents}

An analytical HPLC method adapted from Din et al. [8] was used to evaluate the purity of the compounds obtained. A Phenomenex Hypersil $3 \mu \mathrm{C} 18$ column $(250$ by $4.6 \mathrm{~mm})$ with a flow rate of $1 \mathrm{~mL} / \mathrm{min}$ was used. The mobile phases were $1 \%$ aqueous orthophosphoric acid (A) and methanol (B). The gradient system started with $100 \% \mathrm{~A}$ and was raised to $58 \% \mathrm{~B}$ within 15 minutes, then to $100 \% \mathrm{~B}$ within next 16 minutes, followed by isocratic elution in $100 \% \mathrm{~B}$ for a further 10 minutes. The compounds were further subjected for mass (LC-MS ToF), 1D NMR FTNMR 600MHz Cryo (Fourier Transform Nuclear Magnetic Resonance 600MHz Cryoprobe) and 1D NMR FTNMR 500MHz (Fourier Transform Nuclear Magnetic Resonance 500MHz) spectrometry.

\section{Bioassay for isolated chemical constituents}

The isolated chemical constituents were evaluated for antibacterial and antioxidant activity at $500 \mu \mathrm{g} / \mathrm{mL}$ using the methods described in section Antibacterial studies and Antioxidant assay. The active chemical constituents were further tested for their (MIC).

\section{Chemical Constituents}

\section{Results and Discussion}

Usnic acid, (1) was obtained as yellow needles from acetone extract of $U$. rubrotincta, (1190 mg, 6.62\% yield); HPLC retention time: 28.76 minutes; Mass spectrometry data showed $345 \mathrm{~m} / \mathrm{z} ;{ }^{1} \mathrm{H}$ NMR data and ${ }^{13} \mathrm{C}$ NMR data, see Table 1; Structure, see Figure 1.

Barbatic acid, (2) was obtained as colorless needles from methanol extract of U. rubrotincta, $(0.13 \mathrm{mg}, 0.31 \%$ yield); HPLC retention time: 29.02 minutes; Mass spectrometry data showed $360 \mathrm{~m} / \mathrm{z} ;{ }^{1} \mathrm{H}$ NMR data and ${ }^{13} \mathrm{C}$ NMR data, see Table 2; Structure, see Figure 1. 
Table 1. ${ }^{1} \mathrm{H}$ and ${ }^{13} \mathrm{C}$ NMR spectral data (CDCl3) for compound (1)

\begin{tabular}{|c|c|c|c|c|}
\hline Analysis & & $\delta \mathbf{H}$ & & $\delta \mathrm{C}$ \\
\hline NMR & $\mathrm{C}-1$ & & & 198.06 \\
\hline & $\mathrm{C}-2$ & & & 179.39 \\
\hline & $\mathrm{C}-3$ & - & $\mathrm{s}, 1 \mathrm{H}, \mathrm{OH}-3$ & 155.22 \\
\hline & C-4 & 5.986 & $\mathrm{~s}, 1 \mathrm{H}, \mathrm{H}-4$ & 191.73 \\
\hline & $\mathrm{C}-5$ & & & 101.53 \\
\hline & C-6 & & & 98.35 \\
\hline & $\mathrm{C}-7$ & & & 109.33 \\
\hline & C-8 & 13.320 & $\mathrm{~s}, 1 \mathrm{H}, \mathrm{OH}-8$ & 157.51 \\
\hline & C-9 & & & 103.97 \\
\hline & $\mathrm{C}-10$ & 11.039 & $\mathrm{~s}, 1 \mathrm{H}, \mathrm{OH}-10$ & 163.88 \\
\hline & C-11 & & & 105.24 \\
\hline & C-12 & & & 59.08 \\
\hline & $\mathrm{C}-13$ & 1.766 & $\mathrm{~s}, 3 \mathrm{H}, \mathrm{Me}-13$ & 27.93 \\
\hline & C-14 & & & 200.37 \\
\hline & C-15 & 2.669 & s, $3 \mathrm{H}, \mathrm{Me}-15$ & 32.14 \\
\hline & $C-16$ & 2.111 & s, $3 \mathrm{H}, \mathrm{Me}-16$ & 7.56 \\
\hline & $\mathrm{C}-17$ & & & 201.80 \\
\hline & C-18 & 2.684 & s, $3 \mathrm{H}, \mathrm{Me}-18$ & 31.31 \\
\hline
\end{tabular}

Notes: Chemical shift values $\delta$ in ppm.

Table 2. ${ }^{1} \mathrm{H}$ and ${ }^{13} \mathrm{C}$ NMR spectral data (CDCl3) for compound (2)

\begin{tabular}{|c|c|c|c|c|}
\hline \multirow[t]{2}{*}{ Analysis } & \multicolumn{3}{|l|}{$\delta \mathbf{H}$} & \multirow{2}{*}{$\begin{array}{c}\boldsymbol{\delta} \mathbf{C} \\
110.17\end{array}$} \\
\hline & $\mathrm{C}-1$ & & & \\
\hline & $\mathrm{C}-2$ & & & 152.23 \\
\hline & $\mathrm{C}-3$ & & & 104.25 \\
\hline & $\mathrm{C}-4$ & 3.930 & $s, 3 \mathrm{H}, \mathrm{MeO}-4$ & 162.32 \\
\hline & C-5 & 6.559 & $s, 1 \mathrm{H}, \mathrm{H}-5$ & 106.19 \\
\hline & C-6 & & & 140.16 \\
\hline & $\mathrm{C}-7$ & & & 170.01 \\
\hline & C-8 & 2.069 & $s, 3 \mathrm{H}, \mathrm{Me}-8$ & 6.53 \\
\hline & C-9 & 2.706 & $s, 3 \mathrm{H}, \mathrm{Me}-9$ & 23.59 \\
\hline & $\mathrm{C}-4-\mathrm{OMe}$ & & & 54.78 \\
\hline & $\mathrm{C}-1$, & & & 162.27 \\
\hline & C-2' & & & 110.50 \\
\hline & C-3, & & & 115.98 \\
\hline & C-4, & & & 162.77 \\
\hline & $\mathrm{C}-5$ & 6.575 & $s, 1 \mathrm{H}, \mathrm{H}-5$ & 140.75 \\
\hline & C-6' & & & 115.70 \\
\hline & $C-7^{\prime}$ & & & 173.77 \\
\hline & C- 8 & 2.054 & s, $3 \mathrm{H}, \mathrm{Me}-8^{\prime}$ & 7.99 \\
\hline & C-9' & 2.595 & $s, 3 \mathrm{H}, \mathrm{Me}-9^{\prime}$ & 24.30 \\
\hline & & - & $s, 1 \mathrm{H}, 2-\mathrm{OH}$ & \\
\hline
\end{tabular}

Notes: Chemical shift values $\delta$ in ppm. 
<smiles>[Y5]C(=O)C1=C(O)C=C2Oc3c(C([Y19])=O)c(O)c(C)c(O)c3[C@]2([Y13])C1=O</smiles>

(1)<smiles>COc1cc(C)c(C(=O)Oc2cc(C)c(C(=O)O)c(O)c2[N+](=O)[O-])c(O)c1CO</smiles>

(3)<smiles>[3H]CC[CH+]c1cc(OC)c(OC(=O)c2c(O)cc(OC)cc2[CH+]CC[18F])c(O)c1C(=O)O</smiles>

(5)<smiles>COc1cc(C)c(C(=O)Oc2cc(C)cc(C(=O)O)c2O)c(C)c1O</smiles>

(2)<smiles>CC(=O)c1c(N)cc(OOC(=O)c2c([N+](=O)[O-])cc(O)c(C=O)c2O)c([N+]#N)c1O</smiles>

(4)<smiles>COc1cc(O)c(C(=O)Oc2c(OC)cc([CH+]C[Te])c(C(=O)O)c2O)c([CH+]C#[W])c1</smiles>

(6)

Figure 1. Chemical structure of (1) Usnic acid, (2) Barbatic acid, (3) 8-Hydroxybarbatic acid, (4) Atranorin, (5) Hyperhomosekikaic acid and (6) Sekikaic acid 
8-Hydroxybarbatic acid, (3) was obtained as colorless crystals from methanol extract of U. rurbotincta, (5.18 mg, $0.01 \%$ yield); HPLC retention time: 28.94 minutes; Mass spectrometry data showed $391.29 \mathrm{~m} / \mathrm{z} ;{ }^{1} \mathrm{H}$ NMR data see Table 3; Structure, see Figure 1.

Atranorin, (4) were obtained as colorless prisms from acetone extracts of $R$. dumeticola, (51.28 $\mathrm{mg}$, 0.29\% yield); HPLC retention time: 29.05 minutes; Mass spectrometry data showed $373.11 \mathrm{~m} / \mathrm{z} ;{ }^{1} \mathrm{H}$ NMR data and ${ }^{13} \mathrm{C}$ NMR data, see Table 4; Structure, see Figure 1.

Table 3. ${ }^{1} \mathrm{H}$ NMR spectral data $(\mathrm{CDCl} 3)$ for compound (3)

\begin{tabular}{lll}
\hline Analysis & \multicolumn{1}{c}{$\boldsymbol{\delta H}$} & \\
\hline & 1.185 & $\mathrm{~s}, 3 \mathrm{H}, \mathrm{Me}$ \\
& $2.023,2.031$ & $\mathrm{~s}, 3 \mathrm{H}, \mathrm{Me}$ \\
2.104 & $\mathrm{~s}, 3 \mathrm{H}, \mathrm{Me}$ \\
2.522 & \\
2.556 & \\
2.618 & \\
3.424 & $\mathrm{~s}, 3 \mathrm{H}, \mathrm{OMe}-4$ \\
3.836 & $\mathrm{~s}, 2 \mathrm{H},-\mathrm{CH} 2 \mathrm{OH}-8$ \\
6.312 & $\mathrm{~s}, 1 \mathrm{H}, \mathrm{H}-5$ \\
6.478 & $\mathrm{~s}, 1 \mathrm{H}, \mathrm{H}-5$ \\
11.424 & $\mathrm{~s}, 1 \mathrm{H}, 1-\mathrm{OH}$ \\
11.872 & $\mathrm{~s}, 1 \mathrm{H}, 1-\mathrm{OH}$ \\
\hline
\end{tabular}

Notes: Chemical shift values $\delta$ in ppm.

Table 4. ${ }^{1} \mathrm{H}$ and ${ }^{13} \mathrm{C}$ NMR spectral data $(\mathrm{CDCl} 3)$ for compound (4)

\begin{tabular}{|c|c|c|c|c|}
\hline \multicolumn{2}{|l|}{ Analysis } & \multicolumn{2}{|l|}{$\delta \mathrm{H}$} & \multirow{2}{*}{$\frac{\delta \mathrm{C}}{102.901}$} \\
\hline & $\mathrm{C}-1$ & & & \\
\hline & $\mathrm{C}-2$ & 12.503 & $\mathrm{~s}, 1 \mathrm{H}, \mathrm{OH}-2$ & 169.165 \\
\hline & $\mathrm{C}-3$ & 2.678 & s, 3H, Me-9 & 108.606 \\
\hline & C-4 & 12.551 & $\mathrm{~s}, 1 \mathrm{H}, \mathrm{OH}-4$ & 167.552 \\
\hline & C-5 & 6.392 & $\mathrm{~s}, 3 \mathrm{H}, \mathrm{Me}-5$ & 112.926 \\
\hline & C-6 & & & 152.527 \\
\hline & $\mathrm{C}-7$ & & & 169.776 \\
\hline & $\mathrm{C}-8$ & 10.349 & $\mathrm{~s}, 1 \mathrm{H}, \mathrm{CHO}-8$ & 193.932 \\
\hline & C-9 & & & 24.130 \\
\hline & $\mathrm{C}-1$ & & & 116.849 \\
\hline & $\mathrm{C}-2$ & 11.962 & $\mathrm{~s}, 1 \mathrm{H}, \mathrm{OH}-2$ & 162.949 \\
\hline & C- 3 , & & & 110.318 \\
\hline & C-4, & & & 152.037 \\
\hline & $\mathrm{C}-5$ & 6.507 & $\mathrm{~s}, 1 \mathrm{H}, \mathrm{C}-5$ & 116.091 \\
\hline & C-6' & & & 139.956 \\
\hline & $\mathrm{C}-7$ & & & 172.285 \\
\hline & C- 8 & 2.080 & s, $3 \mathrm{H}, \mathrm{Me}-8^{\prime}$ & 25.681 \\
\hline & C-9' & 2.536 & s, 3H, Me-9 & 9.456 \\
\hline & COOMe-7' & $3.969,3.979$ & s, $3 \mathrm{H}, \mathrm{COOMe}-7$ & 52.444 \\
\hline & - & & & 29.787 \\
\hline
\end{tabular}

Notes: Chemical shift values $\delta$ in ppm. 
Hyperhomosekikaic acid, (5) were obtained as colorless plates from acetone extract of $R$. dumeticola, (4.92 mg, $0.20 \%$ yield); HPLC retention time: 27.87 minutes; Mass spectrometry data showed $480 \mathrm{~m} / \mathrm{z} ;{ }^{1} \mathrm{H}$ NMR data see Table 5; Structure, see Figure 1.

Sekikaic acid, (6) were obtained as colorless prisms from acetone extracts of R. dumeticola, (4.73 $\mathrm{mg}, 0.20 \%$ yield); HPLC retention time: 29.45 minutes; Mass spectrometry data showed $406 \mathrm{~m} / \mathrm{z}$; 1H NMR data see Table 6; Structure, see Figure 1.

Table 5. ${ }^{1} \mathrm{H}$ NMR spectral data $(\mathrm{CDCl} 3)$ for compound (5)

\begin{tabular}{lll}
\hline Analysis & $\boldsymbol{\delta H}$ & \\
\hline NMR & $0.913,0.926,0.938$ & $\mathrm{t}, 3 \mathrm{H}, \mathrm{Me}-5^{\prime}$, \\
& $0.985,0.997,1.009$ & $\mathrm{t}, 3 \mathrm{H}, \mathrm{Me}-5^{\prime}$, \\
& $1.128,1.138$ & $\mathrm{~m}, 6 \mathrm{H}, 3 \mathrm{x}-\mathrm{CH} 2$ \\
& $1.290,1.302,1.314$ & \\
& 2.158 & \\
& $2.93,2.94,2.96$ & $\mathrm{t}, 2 \mathrm{H}, \mathrm{CH} 2-1$, \\
& $2.98,2.99,3.009$ & $\mathrm{t}, 2 \mathrm{H},-\mathrm{CH} 2-1^{\prime \prime}$ \\
& 3.82 & $\mathrm{~s}, 3 \mathrm{H}, \mathrm{MeO}-4$ \\
& 3.876 & $\mathrm{~s}, 3 \mathrm{H}, \mathrm{MeO}-4$ \\
& $6.365,6.369$ & $\mathrm{~d}, 1 \mathrm{H}, \mathrm{H}-3$ \\
& $6.393,6.397$ & $\mathrm{~d}, 1 \mathrm{H}, \mathrm{H}-5$ \\
& 6.548 & $\mathrm{~s}, 1 \mathrm{H}, \mathrm{H}-5$ \\
\hline
\end{tabular}

Notes: Chemical shift values $\delta$ in ppm.

Table 6. ${ }^{1} \mathrm{H}$ NMR spectral data $(\mathrm{CDCl} 3)$ for compound (6)

\begin{tabular}{lll}
\hline Analysis & $\boldsymbol{\delta H}$ & \\
\hline NMR & $0.823,0.838,0.852$ & $\mathrm{t}, 3 \mathrm{H}, \mathrm{Me}$ \\
& $1.195,1.212,1.227$ & $\mathrm{t}, 3 \mathrm{H}, \mathrm{Me}$ \\
& $1.288,1.295,1.302,1.316$ & - \\
& $1.547,1.561$ & $\mathrm{q}, 2 \mathrm{H},-\mathrm{CH} 2$ \\
& $1.608,1.623,1.639,1.654$ & $\mathrm{q}, 2 \mathrm{H},-\mathrm{CH} 2$ \\
& $2.843,2.859,2.874$ & $\mathrm{t}, 2 \mathrm{H},-\mathrm{CH} 2-1 "$ \\
& $2.909,2.925,2.941$ & $\mathrm{t}, 2 \mathrm{H},-\mathrm{CH} 2-1 "$ \\
& $3.343,3.347,3.350$ & \\
3.730 & $\mathrm{~s}, 3 \mathrm{H},-\mathrm{OMe}$ \\
& 3.784 & $\mathrm{~s}, 3 \mathrm{H},-\mathrm{OMe}$ \\
$6.274,6.279$ & $\mathrm{~d}, 2 \mathrm{H}, \mathrm{H}-3$ \\
$6.302,6.308$ & $\mathrm{~d}, 2 \mathrm{H}, \mathrm{H}-5$ \\
6.448 & $\mathrm{~s}, 1 \mathrm{H}, \mathrm{H}-5$ \\
\hline
\end{tabular}

Notes: Chemical shift values $\delta$ in ppm. 


\section{Bioassay of extracts}

The antibacterial activity and the (MIC) of extracts are summarized in Tables 7 and 8 respectively. Acetone extracts of Usnea rubrotincta and Ramalina dumeticola and methanol extracts of Usnea rubrotincta exhibited inhibitory activity against gram positive bacteria $S$. aureus and B. subtilis. However no activity against $E$. coli, gram negative bacterium was observed. The remaining lichen extracts were not active against the three test bacteria. The acetone extract of $R$. dumeticola exhibited highest activity against $S$. aureus followed by acetone and methanol extracts of $U$. rubrotincta. For negative control, DMSO did not exhibit any inhibition against all test organisms.

Table 7. Antibacterial activity of acetone and methanol extracts of various lichens at $500 \mu \mathrm{g} / \mathrm{mL}$ concentration

\begin{tabular}{ccccccccc}
\hline $\begin{array}{c}\text { Test } \\
\text { Organisms }\end{array}$ & \multicolumn{2}{c}{$\begin{array}{c}\text { Usnea } \\
\text { rubrotincta }\end{array}$} & \multicolumn{2}{c}{$\begin{array}{c}\text { Ramalina } \\
\text { dumeticola }\end{array}$} & \multicolumn{2}{c}{$\begin{array}{c}\text { Cladonia } \\
\text { verticillata }\end{array}$} & Chloramphenicol & Vancomycin \\
\cline { 2 - 9 } & A & M & A & M & A & M & & \\
\hline S. aureus & + & + & + & - & - & - & + & + \\
B. subtilis & + & + & + & - & - & - & + & + \\
E. coli & - & - & - & - & - & - & + & + \\
\hline
\end{tabular}

Notes: A, acetone extract; $M$, methanol extract; + , had inhibitory activity against tested bacteria; -, had no inhibitory activity of extract against tested bacteria

Table 8. Minimal Inhibitory Concentration of bioactive extracts against selected gram positive bacteria

\begin{tabular}{|c|c|c|c|c|c|}
\hline \multirow[t]{2}{*}{ Test Organisms } & \multicolumn{2}{|c|}{ Usnea rubrotincta } & Ramalina dumeticola & Chloramphenicol & \multirow[t]{2}{*}{ Vancomycin } \\
\hline & \multicolumn{4}{|c|}{ Minimal Inhibitory Concentration $(\mu \mathrm{g} / \mathrm{mL})$} & \\
\hline S. aureus & 125 & 500 & 31.25 & 31.25 & 7.81 \\
\hline B. subtilis & 15.63 & 250 & 31.25 & 15.63 & 7.81 \\
\hline
\end{tabular}

Notes: A, acetone extract; $M$, methanol extract

Both acetone and methanol extracts of $U$. rubrotincta showed activity against gram positive bacteria. The lowest MIC $(15.63 \mu \mathrm{g} / \mathrm{mL})$ was observed for acetone extract of $U$. rubrotincta against $B$. subtilis comparable to chloramphenicol. A similar activity against $B$. subtilis and $S$. aureus was reported for Usnea barbata acetone extract with MIC value of $0.1 \mathrm{mg} / \mathrm{mL}$ [16]. R. dumeticola acetone extract showed good antimicrobial activity against both gram positive bacteria with MIC values though it was approximately four times less potent than vancomycin (Table 8). Lichen from the same genus, Ramalina farinacea was also reported active against some gram positive bacteria including B. subtilis and S. aureus at MIC value of $264 \mu \mathrm{g} / \mathrm{mL}$ and $132 \mu \mathrm{g} / \mathrm{mL}$ respectively [17]. All the lichen extracts in this study showed no activity against gram negative bacteria. These findings are closely in agreement with report by Burkholder et al. [18] whom reported no activity of 42 tested lichens against gram negative bacteria E.coli.

The phenol and flavonoid contents of all three lichens were in the range of $43.12-101.62 \mathrm{mg}$ of GAE/g extract and $24.92-165.03 \mathrm{mg}$ of QE/g extract respectively. The DPPH assay showed scavenging activity lower than $50 \%$ of for all the studied lichens at $500 \mu \mathrm{g} / \mathrm{mL}$. Results are summarized in (Table 9). 
Table 9. Total phenolic content (TPC), Total flavonoid content (TPC) and DPPH radical scavenging activity of the lichen extracts

\begin{tabular}{llccc}
\hline Sample & $\begin{array}{c}\text { TPC } \\
\text { (mg) of (GAE)/g dry } \\
\text { weight of extract }\end{array}$ & $\begin{array}{c}\text { TFC } \\
\text { mg of }(\mathbf{Q E}) / \mathbf{g} \text { dry } \\
\text { weight of extract }\end{array}$ & $\begin{array}{c}\text { \% Scavenging of DPPH } \\
\text { at 500 } \boldsymbol{\mu g} / \mathbf{m L}\end{array}$ \\
\hline Acetone & RD & $101.62 \pm 3.51$ & $24.92 \pm 1.06$ & $27.21 \pm 1.61$ \\
& U.R & $63.05 \pm 3.27$ & $165.03 \pm 0.62$ & $19.31 \pm 0.25$ \\
& C.V & $101.37 \pm 3.31$ & $108.09 \pm 3.95$ & $33.09 \pm 0.84$ \\
Methanol & R.D & $48.74 \pm 0.84$ & $42.77 \pm 1.13$ & $16.4 \pm 2.99$ \\
& U.R & $43.12 \pm 1.14$ & $98.48 \pm 2.13$ & $11.42 \pm 1.96$ \\
& C.V & $48.61 \pm 0.87$ & $79.20 \pm 1.65$ & $17.25 \pm 2.98$ \\
Trolox & & & & $98.19 \pm 0.66$ \\
\hline
\end{tabular}

Another study [19] recorded (TPC: $115 \mathrm{mg}$ of (GAE)/g dry weight of extract) and (TFC: $1.625 \mathrm{mg}$ of rutin equivalent/g dry weight of extract) values of a different species of Usnea lichen which is Usnea longissima. The same study also reported high antioxidant activity (IC50 $=0.10 \mathrm{mg}$ dry material). Phenolic compounds are a type of antioxidant agents which can adsorb and neutralize the free radicals [20], in which the phenol content in present study is lower than reported study [19]. This explains the low antioxidant activity of $U$. rubrotincta compared to $U$. longissima. Cladonia foliacea was investigated for its TPC and DPPH scavenging activity [21], which also reported low phenolic content (TPC: $78.12 \mathrm{mg}$ of (GAE)/g dry weight of extract) and weak scavenging activity at (IC50: 1000 $\mu \mathrm{g} / \mathrm{mL}$ ) which is in accordance with the present study. Lichen from the genus Ramalina, Ramalina peruviana was investigated for its phenolic content, as well as its free radical scavenging activity [9]. They also reported lowest total phenolic content in $R$. peruviana ( $27.1 \mathrm{mg} \mathrm{GAE} / \mathrm{g}$ extract) compared to a few other lichen species studied, however the free radical scavenging activity was found to be relatively strong at (IC50 $=60.66 \mathrm{mg}$ dry material). $R$. dumeticola was found to contain higher phenolic content but the free radical scavenging activity was only $27.21 \%$. This can be due to different types and concentrations of phenolic compounds present in $R$. peruviana and $R$. dumeticola.

Since the antioxidant activity of the extracts was moderate compared to the antibacterial activity, the extracts selected for subsequent purification and isolation was based on the antibacterial assay results. A total of six secondary metabolites were isolated from acetone and methanol extract of $R$. dumeticola and $U$. rubrotincta. Compound (1) and (4) were found in both the lichen acetone extracts which were identified as usnic acid and atranorin respectively. Compounds (5) and (6) were isolated from acetone extract of $R$. dumeticola which was determined to be hyperhomosekikaic acid and sekikaic acid. With regards to the methanol extract of U. rubrotincta, two more compounds were isolated which were (3), 8-hydroxybarbatic acid and (2), barbatic acid.

Among all isolated chemical constituents, (1) exhibited highest inhibitory activity against both gram positive bacteria at (MIC: $7.81 \mu \mathrm{g} / \mathrm{mL}$ ) which is comparable to standard vancomycin. Atranorin and (2) also showed active inhibitory potential at (MIC: $31.25 \mu \mathrm{g} / \mathrm{mL}$ ) and (MIC: $15.63 \mu \mathrm{g} / \mathrm{mL}$ ) against B. subtilis. The high antimicrobial activity of (1) has been reported previously by Tay et al. [17] in which the lowest inhibitory concentration against $S$. aureus was at (MIC: $3.1 \mu \mathrm{g} / 62.5 \mu \mathrm{l}$ ) and B. subtilis at (MIC: $0.78 \mu \mathrm{g} / 62.5 \mu \mathrm{l}$ ). Compound (1) has been observed to be present in high levels in both the active lichens which could partly explain the potency of the extracts comparable to the standard.

Lauterwein et al. [22] reported a MIC value range from 2 to $16 \mu \mathrm{g} / \mathrm{mL}$ for (1) against gram positive bacteria $S$. aureus. In this study, compound (4) has exhibited stronger activity than the report by Yilmaz et al. [23], where the inhibition potential was only at (MIC: $500 \mu \mathrm{g}$ ) against $S$. aureus and (MIC: $15.63 \mu \mathrm{g}$ ) against B. subtilis. Thadani et al. [24] reported similar activity of (4) and (6) against B. subtilis with inhibition at $100 \mu \mathrm{g} / \mathrm{mL}$ in a disk diffusion assay. 
However, they also reported inhibition activity of (4) and (6) against gram negative bacteria E. coli and no inhibition of (4) and (6) against $S$. aureus. Both reports by Yilmaz et al. [23] and Thadhani et al. [24] have significant difference with this study due to method difference where the reported studies used disk diffusion assay compared to this study which uses the MIC method. Besides that, the bacteria strains are also different between this investigation and Yilmaz et al. [23]. Martins et al. [25] reported MIC values of 50-100 $\mu \mathrm{g} / \mathrm{mL}$ for (2) against various strains of $S$. aureus which is similar to this study where we obtained MIC value of $62.50 \mu \mathrm{g} / \mathrm{mL}$ concentration. Disk diffusion method has its own disadvantages where zone sizes are affected by the media used and by the different growth rates of organisms being tested therefore MIC tests are more accurate with anaerobic bacteria [26].

All compounds exhibited below 50\% scavenging activity against DPPH free radicals except compound (6). Sisodia et al. [27] reported close activity between the standard and compound (6) against DPPH free radical but in this study only 69.57\% scavenging activity was recorded compared to standard Trolox. They also reported minimum scavenging activity of (4) in which is in agreement with this study. Compound (1) which is a phenolic compound, poorly scavenged the DPPH free radical which is in accordance with the findings of Devehat et al. [28] and Thadhani et al. [7]. The radical-scavenging effect of antioxidants on DPPH is a method to quantify the hydrogen donating potency of chemicals and compound (1) does not seem to have the labile hydrogen atoms to bind with the DPPH ions. Devehat et al. [28] studied the antioxidant capacity of compound (2) alongside other lichen compounds but did not report any scavenging activity which is in agreement with our findings where the activity was also very low in contrast to standard. Results are summarized in Table 10.

Table 10. Antibacterial and radical scavenging activity of the isolated compounds

\begin{tabular}{lccc}
\hline Test Compounds & \multicolumn{2}{c}{ MIC $(\boldsymbol{\mu g} / \mathbf{m L})$} & $\begin{array}{c}\text { \% DPPH radical scavenging } \\
\text { at } \mathbf{1 0 0} \boldsymbol{\mu g} / \mathbf{m l}\end{array}$ \\
\cline { 2 - 3 } & S. aureus & B. subtilis & \\
\hline$(1)$ & 7.81 & 7.81 & $44.62 \pm 0.22$ \\
$(2)$ & 62.50 & 31.25 & $29.29 \pm 0.003$ \\
$(3)$ & - & 125 & $36.60 \pm 0.001$ \\
$(4)$ & 62.50 & 15.63 & $27.79 \pm 0.11$ \\
$(5)$ & - & 125 & $13.25 \pm 0.002$ \\
$(6)$ & - & 125 & $69.57 \pm 0.52$ \\
Chloramphenicol & 31.25 & 15.63 & \\
Vancomycin & 7.81 & 7.81 & \\
Trolox & & & $98.41 \pm 0.01$ \\
\hline
\end{tabular}

Notes: - mean no activity detected against tested bacteria

\section{Conclusion}

This is the first report on biological study in of lichens Usnea rubrotincta, Ramalina dumeticola, and Cladonia verticillata from Malaysia. Among the chemical constituents isolated in this study, 8-hydroxybarbatic acid from $U$. rubrotincta and hyperhomosekikaic acid from $R$. dumeticola has been investigated for its antibacterial and antioxidant capacity for the first time and were found to be considerably active against tested bacteria. Usnic acid and atranorin have been identified as active antibacterial agents while sekikaic acid as a considerable antioxidant agent. Further work should be done to enhance the knowledge on these chemical constituents. 


\section{Acknowledgement}

This research was supported by Exploratory Research Grant Scheme (ERGS/1/2012/STG01/UKM/01/3), Ministry of Higher Education, Malaysia, Universiti Kebangsaan Malaysia, Malaysia, and Universiti Sains Malaysia, Malaysia.

\section{References}

1. Denton, G. H. and Karlen, W. (1973). Lichenometry: Its application to Holocene moraine studies in Southern Alaska and Swedish Lapland. Arctic Alpine Research 5:347 - 372.

2. Ahmadjian, V. and Reynolds, J. T. (1961). Production of biologically active compounds by isolated lichenized fungi. Science 133:700-701.

3. Stocker-Worgotter, E. (2008). Metabolic diversity of lichen-forming ascomycetous fungi: culturing, polyketide and shikimate metabolite production, and PKS genes. Natural Product Reports 25: 188 - 200.

4. Gauslaa, Y. and Solhaug, K. A. (2001). Fungal melanins as a sun screen for symbiotic green algaein the lichen Lobaria pulmonaria. Oecologia 126: 462 - 471.

5. Emmerich, R., Giez, I., Lange, O. L. and Proksch, P. (1993). Toxicity and antifeedant activity of lichen compounds against the polyphagous herbivorous insect Spodopter alittoralis. Phytochemisty 33:1389-1394.

6. Rankovic, B. and Misic, M. (2008). The Antimicrobial Activity of the Lichen Substances of the Lichens Cladonia furcata, Ochrolechia androgyna, Parmelia caperata and Parmelia conspresa. Biotechnology Biotechnological Equipment 22: 1013 - 1016.

7. Thadhani, V. M., Choudhary, M. I., Ali, S., Omar, I., Siddique, H. and Karunaratne, V. (2010). Antioxidant activity of some lichen metabolites. Natural Product Reports 25: 1827-1837.

8. Din, L. B., Zuriati, Z., Samsudin, M.W., and Helix, J.A. (2010). Chemical Profile of Compound from Lichens of Bukit Larut, Peninsular Malaysia. Sains Malaysiana 39(6): 901 - 908.

9. Stanly, C., Hag Ali, D. M., Keng, C. L, Boey, P.L., and Bhatt, A. (2011). Comparative Evaluation of Antioxidant Activity and Total Phenolic Content of Selected Lichen Species from Malaysia. Journal of Pharmacy Research 4: 2824 - 2827.

10. Eloff, J. N., (1998). A Sensitive And Quick Microplate Method To Determine The Minimum Inhibitory Concentration Of Plant Extracts For Bacteria. Planta Medica 64: 711-713.

11. Singleton. V. L. and Rossi, J. A. Jr. (1965). Colorimetry of total phenolics with phosphomolybdic phosphotungstic acid reagents. American Journal of Enology and Viticulture 16:144-158.

12. Sakanaka S., Tachibana Y. and Okada Y. (2005). Preparation and antioxidant properties of extracts of Japanese persimmon leaf tea (kakinohacha). Food Chemistry 89:569-575.

13. Shimada, K., Fujikawa, K., Yahara, K. and Nakamura T. (1992). Antioxidative properties of xanthone on the auto oxidation of soybean in cylcodextrin emulsion. Journal of Agriculture Food Chemistry. 40: 945-948.

14. Culberson, C. F. (1972). Improved conditions and new data for the identification of lichen products by a standardized thin layer chromatographic method. Journal of Chromatography 72: $113-125$.

15. Culberson, C. F., Culberson, W. L. and Johnson, A. (1981). A Standardized TLC analysis of $\beta$-Orcinol Depsidones. The Bryologist 84 (1):16 - 29.

16. Madamombe, I. T. and Afolayan, A. J. (2003). Evaluation of Antimicrobial Activity of Extracts from South African Usnea barbata. Pharmaceutical Biology: 199 - 202.

17. Tay, T., Ozdemir, T. A., Yilmaz, M., Turk, H. and Kivanc, M. (2004). Evolution of the Antimicrobial Activity of the Acetone Extract of the Lichen Ramalina farinacea and its (+)-Usnic acid, Norstictic acid, and Protocetraric acid Constituents. Zeitschrift fur Naturforschung. C. 59: $384-388$.

18. Burkholder, P, R., Evans, A. W., McVeigh, I. and Thornton, H, K. (1944). Antibiotic Activity of Lichens. Botany 30: $250-255$.

19. Sinha, S, N. (2013). Screening Of Phytochemicals and Assessment of Antioxidant Activity of Usnea Longissima. International Journal of Universal Pharmacy and Life Sciences 3: 2249 - 6793.

20. Florence, O, J, A. and Adedapo, A. (2011). Comparison of the nutritive value, antioxidant and antibacterial activities of Sonchus asper and Sonchus oleraceus. Records of Natural Products 5: 9-42.

21. Mitrovic, T., Stamenkovic, S., Cvetkovic, V., Tosic, S., Stankovic, M., Radojevic, I., Stefanovic, O., Comic, L., Dacic, D., Curcic, M. and Markovic, S. (2011). Antioxidant, Antimicrobial and Antiproliferative Activities of Five Lichen Species. International Journal Molecular Sciences 12: 5428 - 5448. 
22. Lauterwein, M., Oethinger, M., Belsner, K., Peters, T. and Marre, R. (1995). In vitro activities of the lichen secondary metabolites vulpinic acid, (+)-usnic acid and (-)-usnic acid against aerobic and anaerobic microorganisms. Antimicrob. Agents Chemother 39: $2541-2543$.

23. Yilmaz Y., Turk A. O., Tay T. and Kivanc M. (2004). The antimicrobial activity of extracts of the lichen Cladonia foliacea and its (-)-usnic acid, atranorin and fumarprotocetraric consitituents. Zeitschrift fur Naturforschung C. 59: 249 - 254.

24. Thadhani, V. M., Choudhary, M. I., Khan, S. and Karunaratne, V. (2012). Antimicrobial and toxicological activities of depsides and depsidones. Journal of National Science Foundation Sri Lanka 40(1): 43 - 48.

25. Martins, M. C. B., Goncalves de Lima, M. J., Silva, F. P., Azevedo-Ximenes, E., Henrique da Silva, N., and Pereira, E. C. (2010). Cladia aggregata (lichen) from Brazilian Northeast: Chemical Characterization and Antimicrobial Activity. Brazilian Achieve of Biology and Technology 53(1): $115-122$.

26. James H. J. and Mary, J, F. (1998). Antimicrobial Susceptibility Testing: General Principles and Contemporary Practices. Clinical Infectious Diseases 26: 973 - 980.

27. Sisodiaa, R., Geola, M., Vermaa, S., Ranib, A., \& Durejaa, P. (2013). Antibacterial and antioxidant activity of lichen species Ramalina roesleri. Natural Product Research 27(23): 2235 - 2239.

28. Devehat, F., Tomasi, S., Elix, J.A., Bernard, A., Rouaud, I., Uriac, P. and Boustie, J. (2007). Stictic Acid Derivatives from the Lichen Usnea articulata and Their Antioxidant Activities. Journal Natural Products 70: 1218 - 1220 . 